\title{
Correction to: Physical-Mechanical and Antifungal Properties of Pectin Nanocomposites / Neem Oil Nanoemulsion for Seed Coating
}

\section{Priscila de Castro e Silva ${ }^{1} \cdot$ Lívio Antônio Silva Pereira ${ }^{1}$ (I) $\cdot$ Amanda Maria Teixeira Lago ${ }^{2} \cdot$ Michele Valquíria dos Reis $^{3}$. Édila Maria de Rezende ${ }^{4} \cdot$ Gabriel Ribeiro Carvalho $^{2} \cdot$ Juliano Elvis Oliveira $^{5} \cdot$ José Manoel Marconcini $^{6}$}

Published online: 13 November 2019

(C) Springer Science+Business Media, LLC, part of Springer Nature 2019

\section{Correction to: Food Biophysics}

https://doi.org/10.1007/s11483-019-09592-0

The original version of this article unfortunately contained errors. The author name "Michele Valquíria dos Reis" and affiliation were incorrect.

Publisher's Note Springer Nature remains neutral with regard to jurisdictional claims in published maps and institutional affiliations.

The online version of the original article can be found at https://oi.org/ 10.1007/s11483-019-09592-0

Lívio Antônio Silva Pereira

livioanpe@yahoo.com.br

1 Postgraduate Program in Biomaterial Engineering, Federal University of Lavras, Lavras, MG ZIP-37200-000, Brazil

2 Department of Food Science, Federal University of Lavras, Lavras, MG ZIP-37200-000, Brazil

3 Department of Agriculture, Federal University of Lavras, Lavras, MG ZIP-37200-000, Brazil

4 Department of Biology, Federal University of Lavras, Lavras, MG ZIP-37200-000, Brazil

5 Department of Engineering, Federal University of Lavras, Lavras, MG ZIP-37200-000, Brazil

6 Brazilian Agricultural Research Corporation Instrumentation, Rua XV de Novembro, 1452 - Centro, São Carlos, SP ZIP: 13560-970, Brazil 